\title{
17. From Wagga to Waddington: Australians in Bomber Command
}

\author{
Delivered at a conference held in Lincoln, UK, 26-28 May 2000.
}

The main train line from Sydney to Melbourne runs from Central Station south through the Southern Highlands and crosses the high bleak grazing lands of the Great Dividing Range just west of Goulburn. From there the creeks drain into the Lachlan and the Murrumbidgee, and like the train line the rivers make their way west.

At Junee the train line branches, with the Melbourne line going south through Wagga and the Hay line curving away to the west, a straight line alongside the twists and loops of the bed and billabongs of the Murrumbidgee. Just west of Junee at Marrar the country opens out: the southwest slopes become the western plains - 'the sunlit plains extended'. The first of the towns on the Hay line, Coolamon, Ganmain, Matong and Grong Grong squat in rich, red, gently undulating farm land. Spreading box and neat white cypress pine line the fences. Creeks such as Smoky, Dead Horse, Boggy and Frying Pan - names that recur across the Australian landscape - follow wandering depressions south and west towards the river. Wagga, twenty-five miles from Coolamon, is the dominant town of the eastern Riverina.

When Arthur Doubleday was just old enough to be a useful wood-and-water joey, he went with the horse-team and wagon carting wheat to Ganmain. 'Anglia', the Doubledays' home block, named after the area that Arthur's father had left as a child, was thirteen miles out of Ganmain, and it was midday before the ten-horse team brought the wagon around the football oval, through the trees along Boggy Creek and joined the queue of carters waiting to dump their bagged wheat on the lumpers building the giant stacks at the railway siding. There was only one tough pull for the Doubleday team on that thirteen miles, a sharp rise on the Dulah road that tested the trace chains and the couplings, but it was a long way to cart. On their return journey the Doubledays camped in a paddock and came home the next morning. They could not afford to exhaust the team because they had three months' carting to do, and then the team had to be fresh for the cropping.

Arthur Doubleday, born in 1912, the second son in a family of five girls and three boys, went by horse and sulky or rode to the one-teacher Methul school, five miles northwest of 'Anglia'. Having completed his primary schooling, he went as a boarder to the new Yanco Agricultural High School. With its long drive bordered on one side by river red gums and on the other by lush irrigation 
country, Yanco Agricultural High occupied the imposing two-storey red brick homestead built by Samuel McCaughey, the man who had once controlled over 3,000,000 acres and owned more sheep than anyone else in Australia. Those familiar with Yanco's exposed timber interiors, the 'cathedral size stained glass windows', the artificial lake and orchard, were not likely to be intimidated when they entered the most affluent RAF officer's mess. In his three years at Yanco, Arthur Doubleday responded to the work in the paddock, sheds and classrooms, and 'loved' the cricket and football.

Just after Arthur Doubleday left school to work on the family farm, William Brill, another boy from the red soil of the eastern Riverina, went to board at Yanco Agricultural High. 'Clearview', the Brill farm just south of the GanmainMatong road, was well named. From their home at the top of a gently curving slope, the Brills could see the wheat silos nearly three miles away in Matong. The seven Brill children walked downhill to the weatherboard school of Derrain, and although there was twenty years from oldest to youngest, they all had the same teacher, Charles Banfield. He ruled, Fay Brill said, not with a rod of iron, but with a 'switch of the pepper tree'. And when Vic, who was younger than Bill, went on to Wagga Wagga High, Mr Banfield had taught him so well that he learnt no new maths for the first three years. Bill Brill left Yanco in 1930 with his Intermediate Certificate: he had failed Geography and passed with honours in Agricultural Chemistry and Botany.

On 3 September 1939 the Doubledays had all gathered for shearing, and they were sitting around a roaring fire when they heard on the wireless that Australia was at war. They decided that Harry, who was the oldest and had a crook back, would stay home and run the farm, and Arthur and the youngest boy, Jim, would go to war. There was, Arthur said, a 'lot more of the Mother Country attitude' in him, and he thought he was going 'home to fight'. By 1939 the Doubledays were farming the home block and two others, 'Dulah' and 'Hopewell'. The horse teams were gone, and the Doubledays had tractors, and their wheat went down the road in a cloud of dust. They owned the first semi-trailer in the district. The Brills too had switched to tractors in the early 1930s, and Ken the oldest boy had married and taken up his own block at Landervale on the Grong GrongArdlethan road. Bill went north to work with Ken, and while there he met and courted Ilma Kitto who was the head (and only) teacher at Landervale.

'Anglia' was less than twenty miles from 'Clearview', and Arthur Doubleday and Bill Brill knew one another, in the way that country people knew about each other. They sometimes saw each other, or heard talk when they were at dances, or sheep sales, or waiting at the wheat silos. And the people of Coolamon and Matong were brought together by one of the few significant cultural forces that divide white Australians by place: they were within the northeast frontier of Australian rules football that stretched south through Victoria to Tasmania and 
west to the Indian Ocean. Bill played in the black and white of Matong and Arthur in the green of Methul. Matong and Methul were in different leagues, but Arthur and Bill could read about each other in the Coolamon-Ganmain Farmers' Review, and they certainly would read about Ken Brill, one of the stars in the strong South Western District League. By 1939 Arthur no longer ran onto the clearing in the trees that served as the Methul oval: a damaged knee had ended his football days. On the mechanised farm, Arthur had retained his interests in horses - he did some horse-breaking around the district and rode in buck-jumping shows. Bill, too, was still interested in horses. He had joined the local militia unit, the 21 st Light Horse, and he was proud of his mount, Peanut.

On 19 April 1940 Brill was tested to see if he was a suitable candidate for aircrew training. The men on the interviewing panel pencilled in their impressions: 'rather slow chap but is intelligent', 'neat and respectful', and 'not striking. Quiet country chap'. They noted that he was a 'grade' footballer and was interested in cricket and swimming. They thought he would not be commissioned, but decided he might make a wireless operator/air gunner, and put him in the Air Force reserve. About the middle of 1940 Arthur Doubleday was also passed medically fit and satisfied his interrogators, and he too joined the Air Force reserve. Bill and Arthur both said that they were Methodists, Bill said he was a farmer and farm labourer, and Arthur located himself a shade higher on the rural ladder, he was, he said, a 'farmer and grazier'. Bill was twenty-four and Arthur twenty-eight. Both were of medium height with Bill at five feet ten inches slightly taller and more barrel-chested. Bill was, Arthur said, 'strong as a Mallee bull'. As they waited for their call-up, the air force supplied them with exercises in trigonometry, mechanics, theory of flight and Morse code. Bill was eager to show Ilma his work when he solved a difficult equation, and ready for private tuition when the answer was elusive.

Bill and Arthur were called up for service in November. The farm calendar helped Arthur recall the time. It was, he said, just before the 1940 harvest. When Arthur got on the train at Coolamon on Armistice Day, 11 November, Bill was already on board. He had bloodshot eyes and Arthur was suffering from pains in the stomach. Arthur said that if the Germans could see them they would think they didn't have too much to worry about. Bill and Arthur stayed together on the train to Sydney, and on the bus to Bradfield Park Initial Training School. Bill Brill became Leading Aircraftsman 402933, and Arthur Doubleday 402945, just a dozen numbers separating them. When they left Bradfield Park both had been selected for pilot training, and both were sent to do their elementary flying at Narrandera, just a few miles from Yanco Agricultural High, and less than twenty miles by Tiger Moth from Landervale. Arthur and Bill could check their navigation by glancing out of the cockpit and seeing how Ken and Harry were getting on with the harvest. From the end of January and into February the 
novice pilots tested themselves with side slips, steep turns, instrument flying, forced landings and aerobatics. After just two months both left Narrandera, having satisfied their instructors that they should continue to train as pilots. Brill had gone solo after just seven hours of dual instruction, and he had logged twenty-five hours as a single pilot in the Riverina's summer turbulence.

As applicants were numerous, those selecting aircrew could afford to set a high standard. The instructors could continue to be tough as the trainees went through a succession of schools, each about three months in length: Initial Training School, Elementary Flying Training School, and Service Flying School. During every course there was a strong chance of being 'scrubbed', of failing and being re-mustered to navigators', wireless operators', bomb aimers' and air gunners' schools, or to ground duties. The failure rate, for example, at Uranquinty Service Flying Training School for the 74 trainees who entered 26 course in September 1942 was 21 out of the $74(28 \%)$. It was higher later in the war, up to $50 \%$. And all who went to Uranquinty had already done about sixty hours on a Tiger Moth. That is, they had passed the initial demanding tests.

Those who qualified as aircrew could believe that they had joined the elite. They were going to do something that continued the traditions of the aces of the Great War and they knew it was going to test to the utmost their skill and courage. In 1941 Pip Beck, an eighteen-year-old wireless operator in the Woman's Auxiliary Air Force arrived at Waddington, a Bomber Command airfield near Lincoln. As she went to the Waafery she passed a group of sergeants: 'I knew from the brevets that they wore that these were aircrew, the fabulous beings I admired and hero-worshipped ... they were young gods ... and I blushed for the purple prose of my fancies'. They almost certainly knew how they looked to her.

Brill and Doubleday were about to join that elite, but by age, education and background, they were different from most Australians selected for aircrew training. They were older, they were country boys, and they had completed just three years of high school.

Early in 1941 Ilma Kitto left her school to make a rush trip to Sydney to see her fiancée, but she was too late. Bill Brill, Arthur Doubleday and other Australians had sailed for Canada on 19 March. At No 3 Service Flying Training School at Calgary, Brill and Doubleday learnt to fly the twin-engined Anson, added another fifty hours' solo to their log books, marched in the parade at the Calgary Stampede, graduated with almost equal marks, and were awarded their wings and commissioned as pilot officers. Arthur Doubleday said 'my whole experience in Canada was memorable and pleasurable'. The supervising officer, asked to comment whether there were any points in flying or airmanship that Brill should watch, simply wrote 'Nil'. 
In August 1941 the Australians sailed in a 100-ship convoy from Halifax in Nova Scotia north through thick fog to skirt Greenland and Iceland, and into the Clyde. They came south by train to Bournemouth Personnel Reception Centre, before being posted to 27 Operational Training Unit at Lichfield. By October 1941 Brill and Doubleday were flying Wellingtons across the English counties; it was less than a year since they met on the train that took them to Sydney and Initial Training School. At Lichfield Brill and Doubleday selected their crews. Or perhaps their crews selected them.

Doubleday says it was a 'roundabout thing'. He met a gunner in the mess, and the gunner knew a wireless operator and the wireless operator knew a navigator. Brill's crew was Les Shepard, a bank clerk and another Wagga boy, as second pilot; Hugh Thompson, MA, BSc, an English biologist concerned with the human brain, the 'cool, calm navigator'; Dave Wilkinson, a professional golfer from Yorkshire, radio operator; Kevin Light, an aeronautical engineering student from Sydney, rear gunner; and Fred Lofts, a London salesman, front gunner and bomb aimer. Others who flew at least four operations with them were Tom O'Donohue, a clerk from Brisbane, Peter Gome, an art student from Birmingham, and Ned Walsh from Gympie in Queensland.

Exactly a year after they took their first flights at Narrandera at the height of summer, Brill and Doubleday flew a 460 Squadron Mark IV Wellington on a circuit and landing exercise at Molesworth, just west of Huntingdon. Within days, 460 shifted to Breighton in southern Yorkshire. A new airfield, Breighton in January 1942 was mud, snow, Nissen huts, and three intersecting runways on a high, windswept plain. The Australians soon found the compensation of Bubwith, a village within easy walking distance and with two pubs, the Black Swan and the Seven Sisters. They were known to the Australians as the 'Dirty Duck' and the 'Fourteen Tits', or slightly more decorously, the 'Fourteen Titties'.

Imagine Breighton in January 1942 and the Australians praying for a hard frost so that they might walk on top of the slush and not knee-deep in it. Imagine the crowded mess and Bill Brill takes a couple of gum leaves from an envelope. We are not sure who sent them to him, perhaps his youngest sister Fay, or perhaps his fiancée, Ilma. He lights them and then walks through the mess leaving behind wisps of smoke and the sharp, distinctive smell of burning gum leaves. That smoke was sufficient to transport every Australian, those from the city as well as bush, halfway around the world.

By March 1942460 Squadron was ready to go to war. Brill and Doubleday were among five crews selected to fly on the first operation. The 'rest of the crews' Brill said, 'were envious'. The waiting crews were briefed four times, increasing the tension, before the weather cleared and there could be no more delays. Brill and Doubleday were keen to fly but uncertain how they would 
perform. Doubleday said that before an operation he never felt much different. There was just the increased tension felt by a batsman waiting to walk to the centre, but, he added, the fast bowler always looked more dangerous from the fence than the crease. Brill admitted more anxiety. He wrote about his feelings before another operation:

I wandered around with a feeling of having a half pound of lead in the pit of my stomach ... Perhaps it was fear... How could I get back from this when others who are better than I'll ever be, have fallen on such targets? Will I funk if I'm in a tight spot? Will I let the rest of the boys down? Who am I to hold the lives of five other men in my hands?

It had taken Flying Officers Brill and Doubleday sixteen months from the redsoil paddocks to war in the skies of Europe.

Brill and Doubleday followed a common pattern of Australian airmen going to war in Europe. Nearly all were part of the Empire Air Training Scheme linking the men of the dominions to Britain. The first Australians to train in Canada had gone in July 1940, so Brill and Doubleday were early, but not pioneers: the traffic of Australians in their bright blue uniforms reached its peak in 1943 and early 1944. Some 10,000 Australians completed their training in Canada, just over 647 went to schools in Rhodesia, and most of the 27,000 Australian aircrew who served in Britain had their wings before they left Australia. But they too went by sea across the Pacific, crossed North America by train, and then waited for the convoys that took them into the Mersey or the Clyde.

Among pilots Doubleday was an exception: he wanted to fly bombers, 'the bigger the better'. He had a rational argument, the bomber was the weapon that could hit back, but also his experience with trucks, tractors and harvesters gave him familiarity with heavy machinery. Brill had the same interest and confidence with machinery. At the start of his reflections on his first tour he wrote of the Wellington with its two eighteen-cylinder, twin-row Wasp engines; its slow cruising speed and high fuel consumption; the trouble they had starting it in cold weather; the fact that when they first arrived at Breighton they did not even have a plug spanner; but that during his time on the squadron there was not one case of a Wellington on operations suffering from engine failure. These were the comments from someone who knew a lot about starting International and Bulldog tractors on frosty mornings at Landervale.

For Brill and Doubleday the first operation was greater in anticipation than in reality. They flew as second pilots on a short flight to Emden, one of the closest German ports, and they bombed through cloud. Brill thought they might have 'frightened a cow or two'. On all of his first six operations Brill crossed the North Sea to bomb ports, or to drop leaflets telling the French that 'La Liberation n'est 
plus un espoir. La Liberation est en marche'. He did not see flak until his third trip and did not fly as first pilot until his fifth. And then it was, as he said, 'only poor old le Havre, which every crew in Bomber Command has visited as a "fresher"'. But there were moments of danger. On one mission Brill had a 'torrid time' in flak, and while he could not remember chewing the gum he had with him, on landing he found that repetitive chomping had left his jaw muscles so exhausted he could not open his mouth. Arthur had a more exciting early leaflet raid when he was suddenly 'grabbed' by a radar-controlled searchlight, and he desperately tried to remember all he had been told about evasion. He dived and flattened out as low as he dared, but took a 'hammering' from the flak. The rear gunner, who quite reasonably thought all the enemy fire was directed at him, yelled advice in his Lancashire accent, and they escaped out to sea. Through the first six weeks of operations just one crew in 460 Squadron was shot down.

On 5 April 1942 Brill flew to Cologne, the first mission requiring him to cross extensive occupied territory and attack a defended target. They were given 'quite a reception' crossing the coast, and the 'target itself was an amazing sight'. There was a light flak - 'all colours' - heavy flak and at least a hundred search lights 'holding some poor johnny and plastering him with everything they had ... The haze, the flares, the dozens of dummies and dozens of incendiary loads made the whole place bewildering'. Through the rest of April he flew another six times to Germany: to Hamburg, Essen, Dortmund, Hamburg, Rostock and Kiel. Over Essen, Ned Watch, who had flown with Brill as second pilot, went to close the flare chute just as the flak gunners opened up. Brill said, 'The first burst was rather close, and the blast gave the plane such a kick that it tipped old Ned off his feet. From then on, what with flak bursts and evasive action, Ned was rolled around the fuselage like a pea in a whistle'.

By his eleventh operation Brill was 'beginning to get a little accustomed to being scared'. It was just as well, because Dortmund was a 'cauldron of flak':

Never have I worked so hard, or have I done so much evasive action. The poor kite stood first on one wing, and then on the other, on its tail, and on its nose. The sweat poured off me, half from exertion and half from fright. And still those beams played across us, until I prayed for them to shoot us down and finish it all. Sometimes I wonder if I was a bit mad during part of that show. Can remember looking at times and seeing a big blue beam cutting a track in the sky a few feet above. I screamed laughing ... and cried, 'Ha! Ha! Missed again'.

Brill flew through some thirty miles of 'candles' and, short of fuel and holed with shrapnel, landed at Swanton Morely in Norfolk. 
On his first tour Brill flew eighteen times to Germany, but a raid on France was probably his most hazardous. In May the crews watched anxiously as the moon waxed and the night shortened leaving little darkness to hide a bomber. These were the conditions that Bomber Command needed to make an attack on the Gnome and Rhone works at Gennevilliers, a suburb of Paris. To prevent civilian casualties, the attacking aircraft had to be able to see their target. Only experienced crews were chosen, and those now included both Brill's and Doubleday's. On 29 May seventy-seven bombers took off into cloud and rain squalls. Brill flew at just 175 feet across the Channel so that he was under the cloud and could see exactly where he crossed the French coast. By the time Brill's apprehensive crew reached Paris the weather was clearing, and as they ran in towards the target they were immediately picked up by searchlights. With the bomb doors open they were hit by flak, shrapnel exploded through the aircraft, and cut the hydraulics. Brill 'put in some pretty hard work at the controls' and brought the Wellington over the centre of Paris at about 1000 feet. They were under constant fire as Brill again came over the target, and released the bombs. Flak put the rear turret out of action, and one 1000-pound did not release. They swung for home, as Brill said, with the bomb doors flapping in the breeze, and with a precarious hold on a 1000-pound bomb. They made an emergency landing at White Waltham near Windsor, a short strip, but it did not matter as a flat tyre slowed them on landing. Of the four Wellingtons that had taken off from Breighton, Brill's was the only one to bomb, and his and Arthur Doubleday's were the only ones to get back to England. Brill's Wellington was beyond repair. Brill was given an immediate DFC, the first in 460 Squadron.

When the Wellingtons of 460 Squadron returned from a raid and joined those circling above Breighton waiting for the controller to bring them down, the crews were discouraged from calling each other on the radio. But often they would hear a cheerful Australian voice call, 'How are yer, mate?' And they would know that Brill and Doubleday were checking on each other.

Doubleday finished his tour with a raid on Saarbrucken at the end of July 1942. He was the first in the Squadron to complete a tour, and was awarded a DFC. Brill finished a few days later on 11 August after thirty-one operations. They had taken five months to complete their tours. During that time 460 Squadron had lost twenty-two aircraft, more than its total of eighteen when it began operations. But of course that is the number of aircraft lost on all raids, and is not a measure of their chances of survival. Brill and Doubleday had flown frequently, and that meant that they flew on half of the squadron's operations. Brill had flown on six raids when five per cent or more of aircraft from all squadrons had been destroyed, and on three of those - Essen, Hamburg and Warnemunde - it was seven or more per cent. The average loss per raid over the 
five months had been about three per cent, and that gave a forty per cent chance of survival over a tour. On raids in which Brill had flown, twelve 460 Squadron aircraft had been destroyed.

Don Charlwood, a navigator who completed a tour with 103 Squadron and served as an instructor at 27 Operational Training Unit, Lichfield, wrote:
A few outstanding men recognized that the Command needed their leadership and expertise. Their presence on a squadron lifted morale enormously- provided they stayed alive ... Epitomising such men at Lichfield were two former Riverina farmers, Arthur Doubleday and Bill Brill. They were squadron leaders, each commanding a Lichfield training flight.

It is a fine tribute, yet a senior officer wrote at Lichfield that Brill was just a 'good steady plodder' and gave him four out of ten for initiative. That judgement was in sharp contrast to those who knew Brill as 'charismatic' and a leader of 'outstanding personality'. Perhaps Brill manifested those qualities of leadership only when they were needed - on an operational squadron - but it seems unlikely. In volunteering for a second tour, Brill and Doubleday had committed themselves to another twenty raids.

After eleven months instructing novice crews Brill and Doubleday went to a conversion unit at Wigsley, and there they trained on the Halifax and the Lancaster, the four-engined heavy bombers that had been demonstrating their superiority over the Wellingtons by the time that Brill and Doubleday ended their first tours. Both picked up most of their new crew while still instructing. Ron Fuller says that they were having a beer in the mess at Lichfield when Brill said that he was going back to operations, and he wanted Bob Curtis and Ted Freeman to fly with him. Ron said that he would go with them, but Brill thought there was no chance that he would be allowed to go as he had already done fifty operations, nearly all in North Africa. Fuller insisted he was going anyway, so Brill asked for his release, and to everyone's surprise it was granted. When Doubleday arrived at the Conversion Unit, he still did not have a navigator, but Bob Murphy who was a navigation instructor there was already a friend of Arthur's. Bob said that going on a second tour was 'normally a voluntary job, but they asked me and I couldn't knock 'em back'.

Brill was posted to 463 Squadron, Doubleday to 467. Both had the rank of Squadron Leader, both served as flight commanders, and both squadrons were operating from Waddington. As a re-introduction to war, Brill flew as 'second dickie' to Stettin on 5 January 1944. On the long nine-hour flight there was much more to observe and much of it was disturbing: the density of the bombers in the stream, the use of flares at the turning points, the bombing on coloured marker flares, the efficiency of the German night fighters, the increased use of 
radio and radar for navigation, the demands for precision in navigation and timing, and the intensity of the light over the target area. It was a contrast with Brill's first tour when he had often nosed his way around the target then selected his own bombing run. He decided he would never cross a track marker - the chance of collision was high and the markers attracted the night fighters.

Imagine the mess at Waddington in the winter of early 1944. Outside the cloud is low, and mist and sleet are scudding across the runways. There have been no operations during the day and the forecast means that there will be no air war in western Europe that night. Suddenly there is a cry among the drinkers, 'Clear the runway! Bill Brill will do the impossible'. An indoor runway is cleared of furniture, a sofa is placed across the far end, and beyond it a fine, leather officer's chair is laid on its back. Brill in his socks runs flat out down the runway, grips the top of the sofa with his hands, somersaults, lands in the chair and his momentum turns it upright, leaving Squadron Leader Brill sitting comfortably in the chair. The act is a challenge to other airmen, especially those misled by drink-induced confidence. Soon the end of the runway is littered by pranged airmen who had crash-dived into the wall and floor. The challengers retire to the bar.

Brill and Doubleday returned to operations at the height of the Battle of Berlin. During the first three months of 1944 Bomber Command lost 763 four-engined bombers. The loss rate was greater than the replacement rate - this was a battle that could not be sustained. In those three months both Brill and Doubleday flew on eleven raids, nine of them into Germany, and on those nine raids the average loss rate was 5.5 per cent. At that rate less than one crew in five would complete a full tour.

Brill and his new crew flew their first operation together when they went to Berlin on 20 January, and they went to the 'big city' again on 27 January. As flight commander Brill thought he ought to fly ' $\mathrm{R}$ ' for Robert: it was said to be a jinxed aircraft, a 'chop kite'. On its last flight it had come back with a dead rear gunner - he had died when the oxygen failed. At other times its crew had claimed an engine had lost power, but no faults had shown when the ground staff had tested it. The take-off for the long flight to Berlin was in daylight and Brill flew northeast out over the North Sea and then came south with a tail wind. But one engine did indeed give trouble and Brill was lower and slower than normal. Over Berlin the bomb aimer, Bill McMahon, had just released the bombs when the Lancaster was hit in several places. Brill had been watching gun flashes from below and counting the seconds from the flash, ready to exploit the few seconds that he had to take action if he became the target. So Brill thought they had been hit by flak, but in fact another bomber above them had released its incendiaries on them. One had gone straight through the perspex in the nose of the plane, but McMahon had the presence of mind to pick it up and throw it straight back out again. Other incendiaries hit the navigator's table, severed 
the rudder controls, jammed the rear gunner's escape hatch, and destroyed most of the aircraft's electrical system. As Brill was struggling to regain control, the mid-upper gunner, Tubby Fuller, said there was a plume of flame coming from the port wing, and it was so long it was streaming way past the tail. Brill told the crew to stand-by to bail out, and he put the Lancaster into a dive, a standard way to try and blow a fire out. But he could still see the flames and told the crew to jump. McMahon jettisoned the front hatch and sat with his legs dangling. The navigator, Bluey Freeman, was next in line to jump, but neither was eager to plunge into the inferno of Berlin. Fuller, unable to open the rear door, kicked a hole in it, put his hand through and opened it from the outside, but before he jumped he pulled the emergency hatch in the roof to release the dinghy so that he could have a last look outside. He too decided to stick with the plane, but the wind gripped him and almost sucked him out. The rear gunner, Bill McDonald, said he could not open the rear turret, and so he had no choice: if the plane went down he went with it.

Then Bob Curtis, who had gone up into the astro dome, said that the fire was nearly out. As Brill had levelled off and almost had the plane under control he told Len Smith, the flight engineer, to go around and tell the crew not to jump. On his way back to his turret Tubby Fuller pressed past Curtis whose parachute released, and yards of silk 'spewed out'. Knowing that at any moment his life might depend on his parachute, Curtis tried to stuff silk and cords back into its pack. By this time ' $\mathrm{R}$ ' for Robert was down to 14,000 feet and no one was sure where they were or where they were heading. Holding a torch in his teeth, Freeman worked out their position and gave Brill a course. With limited control, freezing wind streaming in hatches and bomb holes, and bits of aeroplane threatening to tear in the wind, they set off for home. Brill climbed in spite of the cold and in spite of the fact that Smith passed out because of a lack of oxygen and Curtis was vomiting. Curtis kept working on the electrical system, and had some of it repaired before they got back to Waddington. They landed after a nine-hour flight, the second last home. Thirty-three Lancasters did not get back: that was 241 airmen. In Berlin about 700 people were killed, and 20,000 had their homes destroyed. When Brill's crew inspected their plane on the ground they found that seven or eight incendiary bombs had hit them, and the fire in the wing, just missing the fuel tanks, had been caused by a bomb penetrating the wing, burning its way through and falling out.

In a letter home written on the day that they got back to Waddington, Curtis began: 'Dear Dad, Phew! Have I got some news for you ...' He ended: 'Every time I tell this story in the mess or nearby pubs I get a couple of free drinks'. Brill wrote, 'it was not my idea of an evening's entertainment'. They flew again to Berlin three nights later. The Waddington squadrons lost six Lancasters, three from each squadron. 
On his second tour Brill faced extreme danger on two other raids, and both Brill and Doubleday flew on the Nuremberg raid in March, Bomber Command's most costly attack. Nuremberg, Brill said, was the most frightening. He flew through the fragments of a Lancaster that exploded in front of him. One engine was put out of action, another stopped briefly and the rear gunner reported that his turret was not working. Again Brill told the crew to get their parachutes handy, and again they kept flying, and arrived at Waddington an hour after the other crews. By then the weather was closing in, and landing was dangerous. Arthur Doubleday, who was waiting for Brill, said, 'He always caused me some anxiety'. Brill agreed. He told a reporter, 'I am always getting into tight spots'.

As flight leaders Brill and Doubleday deserve much praise for sustaining the morale and efficiency of the two Waddington squadrons through those bleak nights of long flights and high losses during the Battle of Berlin.

From April 1944 Bomber Command switched much of its destructive power from Berlin and other major German cities to preparations for the Normandy landings. The operations against gun emplacements, ammunition dumps, marshalling yards and ports took half the time of the flights to eastern Germany and losses were lighter. Brill flew as deputy controller on the raid to SableSur-Sarthe on 6 May, and saw the bombs turn the ammunition dump into a 'bubbling boiling mass'. The cascades of sparks and the explosions were, Brill said, better than the fireworks he had seen at the Calgary Stampede three years before. No attacking aircraft was lost and a 'good time was had by all'. Arthur Doubleday flew twice on D-Day, 6 June, attacking coastal guns and returning to bomb the railways at Argentan. At the end of his second tour, Doubleday flew twelve successive raids on targets in France.

Brill and Doubleday flew as deputy controllers, and then as controllers. That meant that they had to arrive early, check that the marker flares were correctly located, calculate the wind speed and direction over the target, and redirect those aircraft bombing in the wrong place. Having to stay longer in the target area was not always appreciated by the crews. Before a raid on Cherbourg, Bob Curtis wrote on his route map, 'Controller again - what a bastard'. As controller Brill also felt an increased obligation to bomb accurately. On 8 May over Brest all the defences were alerted and other aircraft were turning for home by the time Brill came in to bomb. He was picked up early by the searchlights but he was determined to hold the plane steady and he refused to look away from his instruments. The Lancaster was 'plastered', but he did not dive and twist until after the bombs were dropped and the confirming photograph taken. As they came away the rear gunner warned that 'odd pieces' were falling off the starboard elevator, and one engine stopped, but they made it home with 140 holes in the fuselage. 
On 11 May 1944 J.R. (Sam) Balmer, commander of 467 Squadron, was killed in action, and Brill was named as his replacement, and he and his crew transferred to the sister squadron at Waddington. It was as Wing Commander that Brill completed his second tour on 4 July 1944. Bob Curtis, the wireless operator and gunner, had actually finished his tour one trip earlier, but volunteered to go on one extra raid so that the crew could stay together. McDonald was not with them. He had filled in with another crew and been killed. Len Smith and Bill McMahon, both on their first tour, had more trips to do after 4 July. Both survived, Bill as a prisoner of war. He had parachuted out over Germany and landed on the roof of a farm house.

Arthur Doubleday was also promoted, but he went to command 61 Squadron, a RAF squadron at Skellingthorpe. He was, he said, the only Australian who had enlisted during the war, and who had acquired his skills through the Empire Air Training Scheme, to command a RAF squadron. Given short warning of his appointment, Doubleday and his crew arrived at Skellingthorpe to find that 61 Squadron had suffered high losses over Berlin, and had just had three aircraft shot down on the Nuremberg raid and another two damaged in crashes. Bob Murphy, Doubleday's navigator, said that they walked into the mess, and 'you could hear a pin drop'. On their second night at Skellingthorpe Doubleday's crew tried to lift morale:

we decided to put on a party ... Got the beer flowing, blackened a few bottoms and put the impressions on the ceiling of the mess - generally livened the place up and within a few weeks we had a tremendous spirit going in the squadron...

Doubleday, who brought a quieter, more deliberate style of leadership to the mess, saved his flamboyance for the air where he flew his aircraft to the extremes of its capacities. Later he said that his six months with 61 Squadron were the most satisfying of his air force career.

Both Brill and Doubleday continued to fly after they completed their second tours. Normally they flew with new crews, or crews they thought needed guidance and encouragement. Doubleday ended up flying fifty-five missions, and Brill fifty-eight. To fly with strangers whose behaviour in air battle was untested added to the risks. On one flight Doubleday heard his bomb aimer say in a matter of fact voice, 'Flak on the port skipper'. It was the sort of statement that normally warned of distant danger, but suddenly shrapnel hit between the inner and outer port engines and Doubleday learnt that he had an unflappable bomb aimer whose voice showed not the slightest trace of excitement even when flak was about to explode a few feet from his nose. On 31 May the crews of 467 were selected for an attack on the railway junction at Saumur in France, but the weather was so bad that Brill told a 'sprog' crew to stay home and he 
and his crew took their place. A month later a new pilot flying 'second dickie' was killed, and the members of the now headless crew faced being sent back to training and again going through crewing-up. Brill took over as pilot and took them on an attack on the railway yards at Limoges in France. He said the 'excitement and enthusiasm expressed by the crew members repaid my small effort'. The excitement was understandable: they nearly collided with another Lancaster on the way in to bomb and had to make another circuit. Below them they could see the opposing armies 'blazing away' at each other. Having been twice briefed to go to Konigsberg but never having made the long flight to the Baltic Port, Brill made a special application to the base commander and was allowed to take a new crew there on 26 August 1944. With the novice pilot acting as flight engineer, they flew the long leg along the Swedish coast looking at the lighted towns below, and the Swedish flak coming up a considerate time after they had gone. It was all, Brill said, 'uncommonly pleasant'.

Brill's crew also say that one night the bombers were moving around the peritrack waiting their turn to take-off when one plane stopped. Brill, who was not flying, drove down to see what was causing the delay. Expecting to be told about a mechanical or electrical fault, he found a traumatised pilot who said he was not in a fit state to fly and, if he did, he would simply kill the rest of the crew. Brill said, 'I will bring you home'. He got his flying kit, and flew the aircraft. Later he arranged for the pilot to be sent to Hugh Thompson, his navigator on the first tour. Thompson, then living in Surrey, provided rest and advice, and the pilot returned to the squadron.

When asked about Brill and Doubleday, a fellow Riverina airman, Reg Bain, said, 'They were mad. They would turn around and have a look'. Where most crews wanted to get in and get out of the target area as fast as possible, both Brill and Doubleday several times made more than one bombing run, and sometimes chose to have a look at what they and others had done. It was not simply a result of responsibilities as flight or squadron commanders or as master bombers. On the twentieth raid of his first tour Brill bombed Emden, went out to sea and then:

I turned the kite around to have a look at the show. It was an unforgettable sight. Must have been seventy or more flares hanging over the centre of the town, with the usual searchlight cones and more than the usual amount of coloured light flak weaving its way up. Fires and gun flashes on the ground and flak bursts in the sky made the picture complete. And the whole issue was reflected in the water.

At other times he wrote of circling low over the target to have a 'looksee'. When the bomb aimer had difficulty locating the target in a raid on Hamburg, Brill 
said on the intercom that he would 'stooge into the centre of the flak' and see what they could find, but "The suggestion was promptly greeted by "Drop the damn things and go home" from every corner of the kite'.

Historians, or all concerned with human behaviour, need to ask why it was that some men who were aware of the casualty rates volunteered to fly a second tour, or to fly the extended tours required in Pathfinder squadrons. The equation that measured life against death was inescapable: the chances of completing a tour of thirty missions when the loss per raid was three per cent was forty per cent - less than an even break. As one said, 'we all knew we were "juggling with Jesus"'. By the time Brill and Doubleday went back to operations there was not a shortage of aircrew - in fact there was a waiting list. The fact that both were to serve as flight and squadron commanders was no comfort: six 463 and 467 Squadron commanders were killed in action, and Rollo Kingsford-Smith and Brill were the only commanders to survive the tough years before the D-Day landings. Yet forces within some men compelled them to go back again. They were uncomfortable about instructing young men to do what they had learnt to do and could do better. Those who survived the trauma of operations often suffered depression, and one way of lifting that depression was to go back into the cycle of the build-up, the intensity of the raid, and the exhaustion of postoperation. Adrenalin, Kingsford-Smith says, 'was God's gift to aircrew'. But adrenalin could come at the cost of dependency and depression. A high-minded sense of duty, guilt, the boredom of instruction, a rational belief that those who were best at operations ought to do them, the lure of the intensity and sense of purpose in life on an operational squadron, and escape from post-trauma depression led men back to operations.

Another puzzle is why Australian aircrew were prepared to fight in a war so far from home, even after Australia was in its own war in the Pacific. But the images that had lured many into the air force - from Biggles to the Battle of Britain - centred in Europe. Australians believed that the great events of the world had their genesis and their resolution in Europe, so to fight there was to be at the determining point of Australia's fate. It was also true that the most advanced aircraft and the best material conditions for aircrew were in England. As Ivan Pellas said, he didn't want to be sent to the back end of nowhere, living in a tent without grog and girls. And Australians now presume a distinction that most Australians did not make in 1939 or 1944: Australians then were both Australian and British. They could be aggressively Australian and critical of much that they saw in England, and still be proudly British. To be absorbed into an Empire Scheme and dispersed into British squadrons was not in conflict with their personal sense of identity. Generally airmen do not regret the combination of policy and chance that took them from Wagga to Waddington - or Bendigo to Breighton. And into a RAF rather than a RAAF squadron. 
In the Australian casualty lists of World War II, two figures stand out: the 8000 who died as prisoners of the Japanese, and the 4000 who died in Bomber Command. In 1945 and into the early 1950s both ex-prisoners and aircrew were accorded national recognition, but by the 1970s both groups had declined in public consciousness. From the early 1980s the ex-prisoners were rediscovered, and Changi, the Burma-Thailand Railway and the Sandakan death march reentered Australian popular history. The men of Bomber Command have remained in relative decline. They have in part been victims of Australian history serving Australia's present.

While neither Arthur Doubleday nor Bill Brill was a national hero when he came home in 1945, there were stories about them in the press, and Arthur was offered pre-selection for two safe seats in Parliament. But when Arthur brought his young English bride back to the farm at Coolamon, there had been prolonged droughts, and the light red soils were on the move. Storms left the house and everything in it veiled in fine dust. Farming and parliament did not seem attractive, and he went into civil aviation, was appointed Regional Director for Queensland in the Department of Civil Aviation, shifted back to New South Wales as Regional Director, and then became Director of the Department of Transport in New South Wales until retiring in 1977.

Bill Brill came home, and married his fiancée school teacher in the Ganmain Methodist church, and stayed in the RAAF. Group Captain Brill died of a heart attack in 1964 when he was just forty-eight years old. Was the officer who in 1940 said he would not make an officer or a pilot at his funeral? Outside their old comrades from Bomber Command, few Australians now know about Brill and Doubleday, the flying farmers from the Riverina. 
This text taken from The Boy from Boort: Remembering Hank Nelson, Edited by Bill Gammage, Brij V. Lal, Gavan Daws, published 2014 by ANU Press, The Australian National University, Canberra, Australia. 